\title{
Studies of the food intake of sheep at a single meal
}

\author{
By J. H. TERNOUTH* AND A. W. BEATTIE \\ Department of Animal Husbandry, Veterinary School, University of \\ Queensland, St Lucia, Brisbane, Queensland, Australia
}

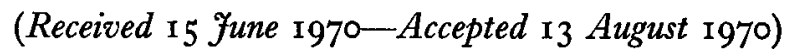

\begin{abstract}
I. Experiments are described in which the food intake and the water intake of sheep at a single meal were measured. The sheep were offered lucerne chaff $a d l i b$. for $2 \mathrm{~h}$ only each day. 2. Following the peritoneal infusion of physiological saline the food intake increased, while the injection of a diuretic before feeding caused the food intake to be decreased.

3. In eight experiments the osmolality of the ruminal liquor was increased by the addition to the rumen of $\mathrm{NaCl}, \mathrm{KCl}$ or the salts of volatile fatty acids in $250 \mathrm{ml}$ water. The decrease in food intake was related to the osmolality, but not to the energy content, of the added electrolyte solution. In a further experiment, sheep receiving a highly digestible lucerne chaff, containing $\mathrm{I} \%(\mathrm{w} / \mathrm{w}) \mathrm{NaCl}$, increased their food intake when water was added to the rumen. Other workers have concluded that gastric osmolality is an important variable in the control of food intake in monogastric animals. The results of the eight experiments now described suggest that ruminal osmolality is of similar importance in ruminants.

4. It is suggested that all these observations are consistent with the theory, which has been proposed for non-ruminant animals, that the food intake at a single meal may be related to the degree of tissue hydration at the beginning of the meal.
\end{abstract}

In some previous experiments with sheep, Ternouth (1968) found that soon after the ingestion of lucerne chaff there was a $10 \%$ reduction in the extracellular volume, but this volume returned to the prefeeding size $3 \mathrm{~h}$ later. In contrast, the osmolality and the concentration of sodium and chloride in the plasma increased, the increase beginning $I \mathrm{~h}$ after the start of feeding and reaching maximal values $3-5 \mathrm{~h}$ later. These results suggest that a reduction of extracellular volume rather than an increased plasma osmolality causes satiety in the ruminant. If this hypothesis were correct, then the food intake of sheep at a single meal should be increased by increasing the extracellular volume and be decreased if the extracellular volume is decreased. The first part of this paper describes the effects upon the food intake of sheep, during a single meal, of increasing the extracellular volume by the infusion of physiological saline into the peritoneal cavity and of decreasing the extracellular volume by the use of a diuretic.

During eating, the ruminant animal secretes copious quantities of saliva; this salivation is likely to be the major cause of the reduction of extracellular volume recorded by Ternouth (1968). During and shortly after the ingestion of food, the osmolality of the ruminal liquor rises above that of plasma (Warner \& Stacy, 1965) and plasma fluids move across the ruminal wall (Engelhardt, I966) causing a further reduction in the extracellular volume. In experiments in which the osmolality of the ruminal liquor was increased by the addition of $\mathrm{NaCl}$ to the food (Wilson, I966) or by intraruminal infusion of volatile fatty acids or their salts (Rook, Balch, Campling $\&$ Fisher, 1963; Montgomery, Schultz \& Baumgardt, 1963; Ulyatt, 1965), there was a depression of food intake which may have been the result of the increased osmolality

* Present address : National Institute for Research in Dairying, Shinfield, Reading RG2 9AT. 
of the ruminal liquor. In the second part of this paper eight experiments are described in which equal osmolar loads of $\mathrm{NaCl}, \mathrm{KCl}$ or the sodium salts of volatile fatty acids were added to the rumen, and the food intake of sheep, at a single meal, was measured. The electrolytes were added to the rumen at the beginning of the feeding period to minimize the variation resulting from their different rates of absorption across the ruminal wall.

Increasing the osmolality of the ruminal liquor was found to decrease food intake; thus it follows that, if the rumen becomes hyperosmolar as a result of the ingestion and fermentation of food, the addition of water to the rumen will lower the ruminal osmolality and should result in an increase in food intake. A final experiment describes the effect of the addition of water to the rumen upon the food intake.

\section{EXPERIMENT AL}

Mature Merino ewes, weighing $32-39 \mathrm{~kg}$, were confined in metabolism crates throughout the experiments. All the sheep had been fed on dry lucerne chaff as their sole food for 2 years. The sheep were trained to consume their total daily intake of lucerne chaff within $2 \mathrm{~h}$. Throughout all the experiments the sheep remained without food for the remaining $22 \mathrm{~h}$ so that they were hungry at the feeding time. Water was available at all times except when removed for experimental reasons (Expts 5 and 6).

\section{Expt I. Effect of the peritoneal infusion of saline}

Three sheep with peritoneal catheters were used in an experiment with a balanced incomplete block design; it lasted 12 consecutive $\mathrm{d}$. The four treatments were randomized so that each sheep received each treatment three times, but no two sheep received the same treatment on any one day. At the beginning of each hour of the feeding period, each sheep was offered I kg of poor-quality lucerne chaff. The uneaten residue was removed and weighed at the end of the hour.

The treatments were: (A) control, drinking water was available; (B) control, no drinking water was available during the $2 \mathrm{~h}$ feeding period; (C) $500 \mathrm{ml}$ sterile physiological saline ( $9 \mathrm{~g} \mathrm{NaCl} / \mathrm{l})$ were infused into the peritoneal cavity, the infusion beginning when the sheep were fed, and drinking water was available; (D) $500 \mathrm{ml}$ sterile physiological saline $(9 \mathrm{~g} \mathrm{NaCl} / 1)$ were infused into the peritoneal cavity, the infusion beginning $30 \mathrm{~min}$ after the start of feeding, and drinking water was available.

The saline (at $39^{\circ}$ ) was infused by gravity drip through the catheter, the infusion being complete in $15 \mathrm{~min}$.

\section{Expt 2. Effect of the intramuscular injection of a diuretic}

Six sheep were fed on good-quality lucerne chaff in a Latin-square experiment. At intervals of 3,2 , I or $0.5 \mathrm{~h}$ and immediately before the beginning of the feeding period a diuretic (Furosemide, ro $\mathrm{mg} / \mathrm{sheep}$; Australian Hoechst) was administered by intramuscular injection. A control treatment in which no diuretic was given was also incorporated in the experimental design.

The food intake during the Ist and and hours of the feeding period, the water intake and the volume of urine voided during the $3 \mathrm{~h}$ before and the $2 \mathrm{~h}$ of feeding were recorded. 


\section{Expts 3-IO. Effect of adding electrolytes to the rumen}

Six sheep with ruminal fistulas were used in these eight experiments. Each experiment was performed on three sheep and lasted ro consecutive d. At the beginning of the feeding period, $250 \mathrm{ml}$ water containing a known quantity of added electrolyte were poured into the rumen. The amounts and type of electrolyte added to the rumen are shown in Table $\mathrm{x}$. The amount of electrolyte given was randomized so that each sheep received each amount of electrolyte twice, but so that no two sheep received the same amount on any one day. The experimental designs were therefore of a balanced incomplete block type.

Table I. Amounts of electrolytes and the osmolalities of the solutions added to the rumens of Merino ezves immediately before the beginning of a $2 h$ feeding period

\begin{tabular}{|c|c|c|c|c|c|c|c|}
\hline \multirow[b]{2}{*}{ Expt } & \multirow{2}{*}{$\begin{array}{c}\text { Sheep } \\
\text { nos. }\end{array}$} & \multirow[b]{2}{*}{ Electrolyte } & \multicolumn{5}{|c|}{ Amount of electrolyte (g) } \\
\hline & & & $\circ$ & I & 2 & 3 & 4 \\
\hline 3 and 5 & $I-3$ & $\mathrm{NaCl}$ & $\circ$ & $5 \cdot 0$ & 10.0 & $15^{\circ} \mathrm{O}$ & $20 \cdot 0$ \\
\hline 4 and 6 & $I-3$ & & $\circ$ & $6 \cdot 4$ & $12 \cdot 8$ & $19 \cdot 2$ & $25 \cdot 6$ \\
\hline 7 & $4-6$ & Acetate* & $\circ$ & $10 \cdot 0$ & $20 \cdot 0$ & $30 \cdot 0$ & $40 \cdot 0$ \\
\hline 8 & $I-3$ & Acetate* & $\circ$ & $5 \cdot 0$ & $10 \% 0$ & $15 \circ$ & 20.0 \\
\hline 9 & $4-6$ & Propionate* & $\circ$ & $6 \cdot 2$ & $12 \cdot 4$ & 18.6 & $24 \cdot 8$ \\
\hline IO & $4-6$ & Butyrate* & ○ & $7 \cdot 3$ & $14 \cdot 7$ & $22 \cdot 0$ & $28 \cdot 3$ \\
\hline \multicolumn{8}{|c|}{ Calculated osmolality of the solutions $\nmid$ (Osm): } \\
\hline \multicolumn{3}{|c|}{ Expts $3^{-6}$ and 8-10 } & 。 & 0.68 & $r \cdot 36$ & $2 \cdot 04$ & $2 \cdot 72$ \\
\hline \multicolumn{3}{|l|}{ Expt 7} & o & $1 \cdot 36$ & $2 \cdot 72$ & 4.08 & $5 \cdot 4$ \\
\hline
\end{tabular}

* The solutions were prepared by adding $\mathrm{NaOH}$ to the solutions of the appropriate volatile fatty acid until the $\mathrm{pH}$ was $6 \cdot 5$.

$\uparrow$ Complete ionization is assumed.

The food and water intakes of the sheep during the ist and and hours of the feeding period were recorded, except in Expts 5 and 6 in which no water was given during the feeding period. In these two experiments the water intakes during the 15 min immediately after feeding were recorded.

During Expts 3-6 the sheep were given a good-quality green lucerne chaff, but in the subsequent experiments the chaff was of poorer quality.

Ruminal liquor $(5 \circ \mathrm{ml})$ was removed from the sheep $\mathrm{I} h$ after the beginning of feeding and the osmolality was determined with an osmometer (Advanced Instruments Inc., Newton Highlands, Massachusetts).

\section{Expt $\mathrm{I}$. Effect of the addition of water to the rumen}

Three sheep with ruminal fistulas were used. The experiment was designed as a balanced incomplete block and lasted for to consecutive d. One litre of water $\left(39^{\circ}\right)$ was poured into the rumen 3,2 and $I \mathrm{~h}$ and immediately before the beginning of feeding. A control treatment, in which no water was added to the rumen, was included in the experimental design. To ensure that the ruminal liquor became hyperosmolar during feeding, the good-quality lucerne chaff, which was offered to all the sheep, contained I $\%(\mathrm{w} / \mathrm{w}) \mathrm{NaCl}$.

Food intake, water intake and the volume of urine voided were measured, as in Expt 2. 


\section{RESULTS}

\section{Expt 1 . Effect of the peritoneal infusion of saline}

The results (Table 2) show that when saline was infused into the peritoneal cavity the food intake was increased. When the saline was infused 30 min after the beginning of the feeding period, the total food intake and the intake for the ist hour of the feeding period were significantly increased when compared with control A. When the infusion was given at the beginning of feeding, the food intakes were similarly increased, but were not significantly different from those in control $\mathrm{A}$. When the results of the treatments in which saline was given (C and D) were averaged and compared with the results of those in which saline was not given ( $A$ and $B$ ), it was found that the sheep that were given the peritoneal infusions of saline had significantly higher intakes, $17 \%$ more food being ingested at that meal.

Table 2. Expt 1. Mean effect of infusions of physiological saline upon the food intake $(g)$ of three Merino ewes

\begin{tabular}{|c|c|c|c|c|c|}
\hline $\begin{array}{l}\text { Feeding } \\
\text { period }\end{array}$ & $\begin{array}{c}\text { Control } \\
\text { A }\end{array}$ & $\begin{array}{l}\text { Control } \\
\text { no drinking } \\
\text { water } \\
\text { B }\end{array}$ & $\begin{array}{c}\text { Saline infusion } \\
\text { at beginning } \\
\text { of feeding } \\
\mathrm{C}\end{array}$ & $\begin{array}{l}\text { Saline infusion } \\
30 \text { min after } \\
\text { beginning of } \\
\text { feeding } \\
\text { D }\end{array}$ & $\begin{array}{c}\text { Standard error } \\
\text { of a mean } \\
\text { (with } 18 \mathrm{df}^{*} \text { ) }\end{array}$ \\
\hline $\begin{array}{l}\text { Ist } h \\
\text { and } h\end{array}$ & $\begin{array}{l}356 \\
161\end{array}$ & $\begin{array}{l}393 \\
\mathbf{I} 33\end{array}$ & $\begin{array}{l}415 \\
177\end{array}$ & $\begin{array}{l}436 \\
\text { I } 98\end{array}$ & $\begin{array}{l}2 I \cdot 4 \\
14 \cdot 5\end{array}$ \\
\hline Total & 517 & 527 & 592 & 634 & 33.5 \\
\hline $\begin{array}{l}\text { Ist } h \\
\text { 2nd h } \\
\text { Total }\end{array}$ & & & & & $\begin{array}{l}16 \cdot 5 \\
\text { II } 2 \\
25 \cdot 8\end{array}$ \\
\hline
\end{tabular}

\section{Expt 2. Effect of the intramuscular injection of a diuretic}

After the intramuscular injection of the diuretic, an extra $400 \mathrm{ml}$ of plasma fluids were lost in the urine (Table 3 ), this diuresis being virtually complete within $\mathbf{I} \mathbf{h}$. The water intake increased after the administration of the diuretic, although the largest increase during the $3 \mathrm{~h}$ before feeding was $\mathrm{I} 70 \mathrm{ml}$. The total food intake was significantly less whenever the diuretic was given; this reduction was largely due to the significantly reduced intake of food during the Ist hour of the feeding period.

These results could have been the result of some effect of the diuretic other than the effect on extracellular volume. The half-life of the diuretic in the blood is known, however, to be $12-15 \mathrm{~min}$, and $60 \%$ of the administered dose appears in the urine within $2 \mathrm{~h}$ (Anonymous, 1963 ). Therefore, as the diuretic produced a similar reduction of food intake regardless of the time of administration, it was concluded that the reduction was the result of the decreased extracellular volume. Alternatively, the reduction of food intake could have been the result of the intramuscular injection procedure rather than the effect of the reduced extracellular volume. This possibility was discounted because, in a separate identically designed experiment, in which another slower-acting diuretic (Hydrochlorothiazide) was injected, there was no increase in 
the urinary flow rate or the amount of water drunk during the $5 \mathrm{~h}$ experimental period nor a reduction in the food intake when the diuretic was given (Ternouth \& Beattie, I968, unpublished).

Table 3. Expt 2. Mean food intake, water intake and urine flow of six Merino ewes after the intramuscular injection of a diuretic, 3, 2, 1, 0.5 or $\circ h$ before feeding

\begin{tabular}{|c|c|c|c|c|c|c|c|}
\hline \multirow{3}{*}{$\begin{array}{l}\text { Time before feeding } \\
\text { that diuretic was } \\
\text { injected }(\mathrm{h})\end{array}$} & & & & \multirow{2}{*}{\multicolumn{2}{|c|}{$\overbrace{\substack{\text { During } \\
3 \mathrm{~h}}}^{\text {Water intake (1) }}$}} & \multicolumn{2}{|c|}{ Urine flow (ml) } \\
\hline & \multicolumn{3}{|c|}{ Food intake $(\mathrm{g})$} & & & $\begin{array}{c}\text { During } \\
3 \mathrm{~h}\end{array}$ & \\
\hline & Ist $h$ & 2nd $h$ & Total & feeding & feeding & feeding & feeding \\
\hline 3 & $533^{*}$ & 259 & $792 *$ & 0.21 & $2 \cdot 00$ & $616 * * *$ & 60 \\
\hline 2 & $512 * *$ & 254 & $766 * *$ & 0.32 & $2 \cdot 06$ & $593 * * *$ & 46 \\
\hline $\mathbf{I}$ & $533^{*}$ & 253 & $786 *$ & $0 \cdot 19$ & $2 \cdot 00$ & $6 \mathrm{I}_{7} * * *$ & $6_{3}$ \\
\hline 0.5 & $509 * *$ & 270 & $780 *$ & 0.27 & $2 \cdot 08$ & $482 * * *$ & I 74 \\
\hline 0 & 540 & 245 & $785^{*}$ & 0.08 & $1 \cdot 94$ & 198 & $35^{8 * * *}$ \\
\hline Control (no diuretic) & 587 & 280 & 868 & 0.15 & $2 \cdot 08$ & $\mathbf{2 3 2}$ & 109 \\
\hline SE of a mean (5o df) & 16.7 & 14.8 & $26 \cdot 1$ & 0.08 & 0.12 & $35 \cdot 1$ & $33 \cdot 0$ \\
\hline
\end{tabular}

\section{Expts 3-10. Effect of adding electrolytes to the rumen}

In Figs. I and 2 are shown the mean values for the food intake, water intake and the osmolality of the ruminal liquor $\mathrm{I} h$ after the beginning of feeding, for each of the five amounts of electrolyte added to the rumen. The results (Table 4) show that as the osmolality of electrolyte was linearly increased, so the food intake linearly decreased, although in Expts 3, 6 and 9 single mean values did deviate from this linearity. This decrease was mainly due to a reduced food intake during the ist hour of the feeding period. Concurrent with the depression of food intake was an increase in the water intake, although the increased water intake during the rst hour of the feeding period was insufficient to dilute the added electrolyte to a solution which was iso-osmolar with plasma.

Comparison of the results of Expt 3 with those of Expt 5 and of Expt 4 with those of Expt 6 (Table 4) indicated that, when water was not available to the sheep, there was a greater rate of reduction of food intake than when water was available. This increased reduction in food intake was mainly the result of a twofold increase in the rate of reduction of food intake during the 2nd hour of the feeding period.

The sheep in Expts 5 and 6 were not allowed water during the $2 \mathrm{~h}$ feeding period, but when at the end of the feeding period their water troughs were returned to them, they drank a quantity of water very similar to the total water intake of the sheep that were allowed water during the feeding period (Expts 3 and 4). In Expts 5 and 6, the osmolality of the ruminal liquor was higher than when water was available (Expts 3 and 4).

In Table 4, the reductions of total food intake (Expts $3^{-10}$ ) were related to the quantity (expressed as the osmolality of the electrolyte solution) and the energy content of the electrolyte added to the rumen. Comparison of the reductions of food intake between experiments showed that the reductions were of the same order when similar osmolar quantities of electrolyte were given under the same experimental conditions 
(Expts 3, 4, 8, 9 and ro). On the other hand, the reductions of food intake were not of the same order when related to the energy content of the electrolytes.

Equations for the total water intake, in terms of the amount of electrolyte added to
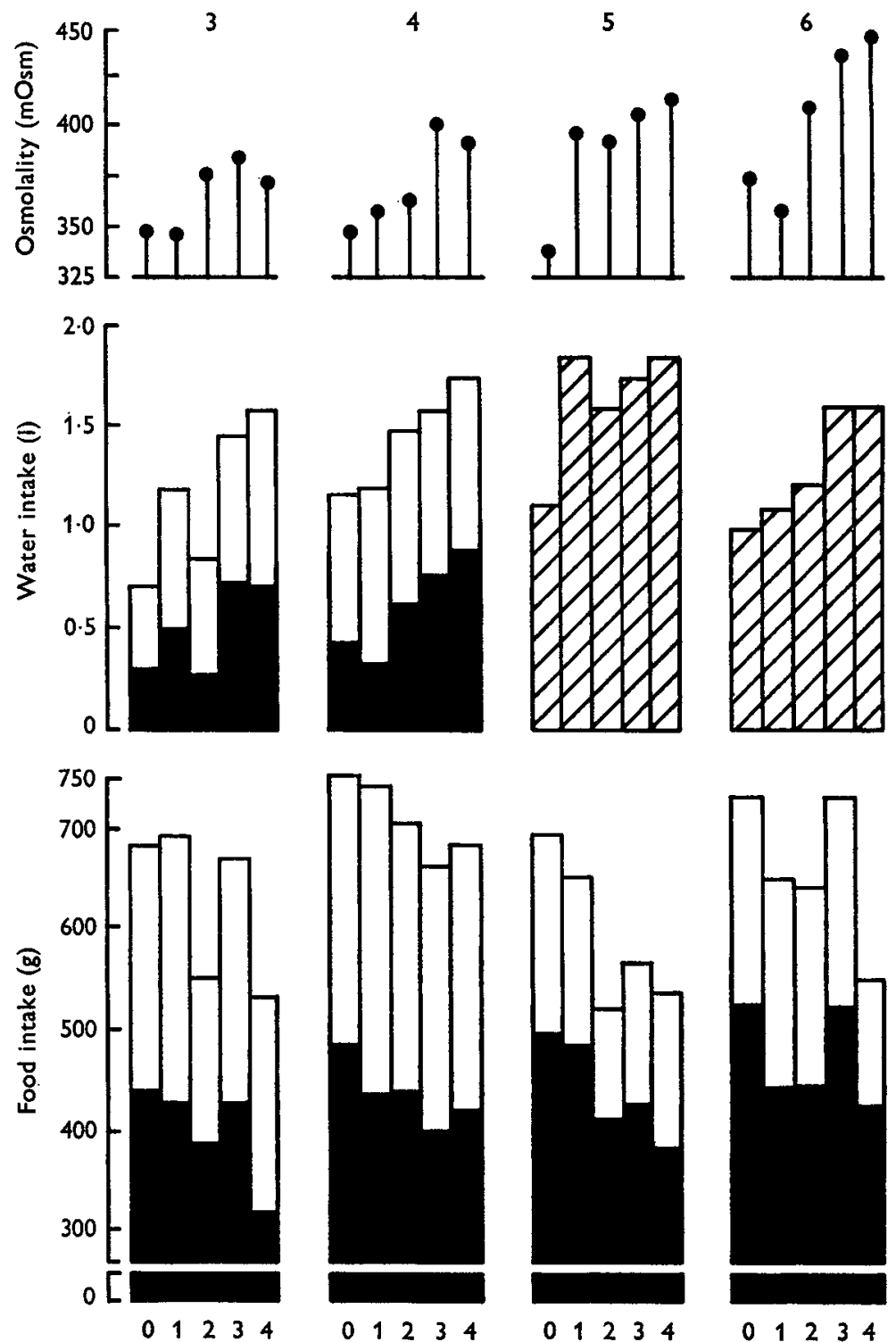

Amount of electrolyte

Fig. 1. Expts 3-6. Effect of the addition of five different amounts of electrolyte (0-4) upon food intake, water intake and the osmolality of the rumen contents of three Merino ewes. In Expts 3 and 5 the electrolyte added was $\mathrm{NaCl}$ and in Expts 4 and 6 the electrolyte was $\mathrm{KCl}$. In Expts 5 and 6 the sheep were not allowed water during the feeding period. (Shaded and unshaded areas represent the intakes for the ist and and $h$ of the feeding period respectively. The hatched area in Expts 5 and 6 represents the water intake for the $15 \mathrm{~min}$ immediately after the completion of the $2 \mathrm{~h}$ feeding period.) 

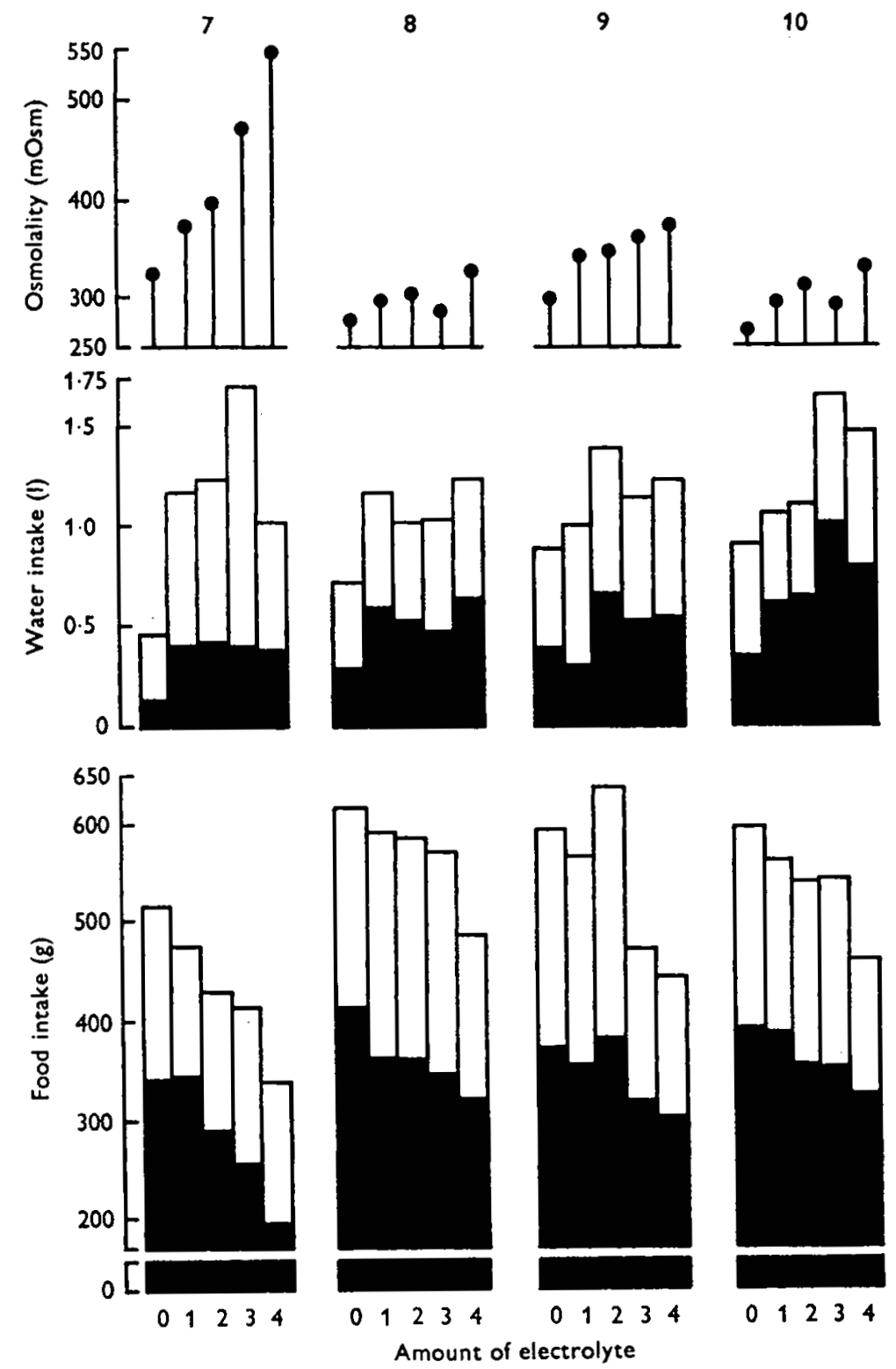

Fig. 2. Expts 7-10. Effect of the addition of five different amounts of electrolyte (o-4) upon the food intake, water intake and the osmolality of the rumen contents of three Merino ewes. The electrolytes added were acetate, acetate, propionate and butyrate for Expts 7, 8, 9 and Io respectively. (The areas are shaded as in Fig. I.)

the rumen, were calculated from the mean values for the five amounts of electrolyte in each experiment. These regression equations were:

$$
\begin{array}{lll}
\text { Expts } 3-6 & \mathrm{WI}=1044+245\left( \pm 5^{6}\right) E & (r=0.7 \mathrm{I}, P<0.00 \mathrm{I}, 18 \mathrm{df}), \\
\text { Expts } 7-10 & \mathrm{WI}=940+1 \mathrm{I} 5( \pm 40) E & (r=0.56, P<0.05,18 \mathrm{df}),
\end{array}
$$


where WI is the water intake $(\mathrm{ml})$ and $E$ is the osmolality of the electrolyte solution (Osm). The regression coefficients for $E$ were almost significantly different from each other $(0.05<P<0.10)$.

Table 4. Reduction in food intake of three Merino ewes as related to the osmolality and metabolizable energy content of the added electrolyte solutions

\begin{tabular}{|c|c|c|c|}
\hline Expt & Electrolyte & $\begin{array}{l}\mathrm{g} \text { chaff/Osm per } 1 \\
\text { electrolyte solution }\end{array}$ & $\begin{array}{r}\text { kcal chaff } \\
\text { electro }\end{array}$ \\
\hline 3 & $\mathrm{NaCl}$ & $47.0 \pm 20.0^{*}$ & \\
\hline 4 & $\mathrm{KCl}$ & $30.9 \pm 9 \cdot 8 * *$ & \\
\hline 5 & $\mathrm{NaCl}$ (no drinking water) & $58 \cdot 5 \pm 15 \cdot 0^{* *}$ & \\
\hline 6 & $\mathrm{KCl}$ (no drinking water) & $40 \cdot 0 \pm 21 \cdot 9$ & \\
\hline 7 & Acetate & $30.9 \pm 10.2 *$ & \\
\hline 8 & Acetate & $4 I \cdot 4 \pm 2 I \cdot 0$ & \\
\hline 9 & Propionate & $58.0 \pm 15.4 * *$ & \\
\hline IO & Butyrate & $42 \cdot 8 \pm 22 \cdot 9$ & \\
\hline
\end{tabular}

$\dagger$ Assumed that the lucerne chaff was $90 \%$ dry matter, digestible energy was $2.7 \mathrm{kcal} / \mathrm{g}$ dry matter and metabolizable energy $=0.82 \times$ digestible energy (Weston, 1966).

I Derived from Blaxter ( 1961 ).

Regression coefficients significant: ${ }^{*} P<0.05 ; * * P<0.01$ ( $14 \mathrm{df}$ ).

Table 5. Expt I I. Effect on food intake, water intake and urine flow of the addition of $\mathrm{I} l$ of water to the rumen of three sheep

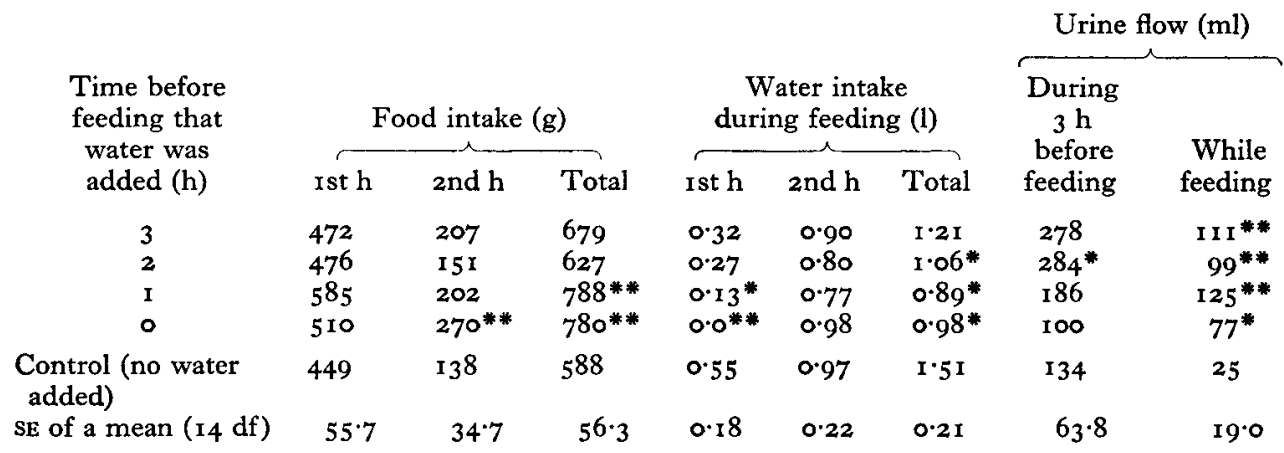

Value significantly different from control value: $P<0.05 ; * P<0.01$.

Partial regressions for the total water intake, in terms of the amount of electrolyte added to the rumen and the food intake, were calculated from the same mean values. These equations were:

Expts $3-6$ WI $=1010+262( \pm 70) E+3 \cdot 7( \pm 9 \cdot 1)$ FI $\quad(R=0.72, P<0.001,17 \mathrm{df})$, Expts $7-10 \quad \mathrm{WI}=1020+221( \pm 70) E+23 \cdot 0( \pm 12 \cdot 7) \mathrm{FI}$

$$
(R=0.66, P<0.01, \mathrm{I} 7 \mathrm{df}),
$$

where $\mathrm{FI}$ is the food intake $(\mathrm{g})$ in excess of $600 \mathrm{~g}$. In the partial regression equations, the coefficients for $E$ were not significantly different from each other, but the coefficients for $\mathrm{FI}$ were almost significantly different from each other $(0.05<P<0.10)$. Only in Expts 7-10, in which the sheep were being fed on poor-quality lucerne, did the coefficient for food intake improve the correlation coefficient, although the significance of the regression coefficient for FI was low (0.05 $<P<0.10)$. In Expts 
7-10, when the coefficient for FI was included in the regression equation, the coefficient for $E$ was greatly increased in magnitude so that it was similar to those calculated for Expts 3-6 in both the simple and partial regression equations.

\section{Expt I I. Effect of the addition of water to the rumen}

In this experiment, feeding the sheep on highly digestible lucerne chaff which also contained $\mathrm{I} \% \mathrm{NaCl}$ was expected to exaggerate the increase in ruminal osmolality. The results (Table 5) show that, whenever water was added to the rumen, food intake increased markedly, but the increase was significant only when the water was given I h or immediately before feeding. Although the voluntary intake of water by the sheep was decreased whenever water was added to the rumen, the sheep that received water had a higher total water intake than the control sheep.

Whenever water was added to the rumen, the amount of urine voided during the feeding period increased significantly.

\section{DISCUSSION}

Before discussing the results, it is pertinent to emphasize some features of these experiments. As the sheep were not given any choice of food and none of the experimental treatments involved any variation in the diet offered, the only function of the oro-pharyngeal area would have been to act as a meter for the amount of food eaten; food selection and palatability appeared to play no part in determining intake. The sheep were hungry at the beginning of the feeding period and were trained to eat all their food in one meal, so that they were likely to stop eating at a definite physiological end-point. The purpose of all the experiments was to determine how the treatments altered the weight of food ingested at the meal when the treatment was imposed. It was observed that the sheep had generally finished eating and were often lying down at the end of the feeding period, suggesting that they were satiated. The design of each experiment was a randomized balanced incomplete block or a Latin square, and the mean results show the effects of the treatments upon the food intake at a single meal, i.e. the food intake required by the sheep to change from a physiological state of hunger to one of satiety. Although any residual effect of the treatments upon the food intake on the following day could not be specifically removed from the results, the order in which the treatments were given was randomized. In addition, it was noted that, in all the experiments in which the treatments reduced food intake, the reduction in food intake was least marked in the 2nd hour of the feeding period; thus an appreciable residual effect on the food intake of the following day seems unlikely. In the experiments in which electrolytes were added to the rumen, the effect of the different rates of absorption of the various ions across the ruminal wall was minimized by adding the electrolytes to the rumen at the beginning of feeding.

Brobeck (1960) and Anand (1961), in their reviews of the nervous control of food intake, have concluded that food intake may be limited by 'tissue dehydration'. R. L. Cort found that increasing the extracellular volume of rats by the subcutaneous injection of procainized saline increased food intake (quoted by Cort, I 966). Recently, Gutman \& Krausz (1969) have been able to increase and decrease the food intake of rats by increasing and decreasing their extracellular volumes. Lepkovsky, Lyman, 
Fleming, Nagumo \& Dimick (I957) reported that rats mobilized their tissue fluids to maintain their gastric fluids at a water content of $49 \%$. They suggested that the food intake was limited by the quantity of tissue fluid available to maintain this water content of the stomach contents. In our experiments it was observed that, when the sheep were allowed to eat a single meal, their food intake was apparently related to the state of extracellular hydration. When the peritoneal infusions of saline were given, food intake increased and, alternatively, it decreased after the administration of a diuretic. Assuming that these treatments did cause an increase and a decrease respectively in the extracellular volume, then these results are consistent with the hypothesis that the 'tissue dehydration' theory of the control of food intake is applicable to the sheep.

For the monogastric animal, Morgan (I964) has concluded that 'osmotic pressure is an important variable, if not the principle variable in the gastric inhibition of eating'. This conclusion was based on the increases and decreases of food intake recorded by a number of workers following the injection of hyperosmolar and hypo-osmolar solutions of sugars, electrolytes and urea into the stomach. From our results (Expts $3^{-1}$ I), Morgan's conclusions can be extended to include the ruminal inhibition of food intake. The reduction in food intake was not related to the energy content of the electrolytes, since the addition of $\mathrm{NaCl}, \mathrm{KCl}$ or the salts of volatile fatty acids (Expts 3, 4, 8, 9 and Io) caused similar reductions in food intake. Comparison of the depression of food intake following the addition of equal quantities of the salts of the volatile fatty acids (see results of Expts 8, 9 and 10 in Table 4), shows that the reduction of intake (for each kcal of electrolyte added) was greatest for acetate and markedly least for butyrate.

In the introduction, it was suggested that the reduction of food intake following the intraruminal infusion of electrolytes could be due to a reduction of extracellular volume. The changes of food and water intake observed when electrolytes (Expts $3^{-I O}$ ) and water (Expt II) were placed in the rumen provide only indirect evidence to support this suggested mechanism. Duodenal osmo-receptors are known to be important in the control of gastric emptying in man (Hunt \& Pathak, 1960; Elias, Gibson Greenwood, Hunt \& Tripp, I968) and these or osmo-receptors placed within the stomachs of the sheep may represent an alternative sensory mechanism for inhibiting food intake and increasing water intake.

Brobeck ( 1960 ) said that animals have no direct method of measuring energy intake, and so any adjustment of the food intake to the addition of energy-containing molecules to the rumen must be of a long-term nature. Kennedy (196r) concluded that there is such a long-term control of food intake which modifies the level of food intake so that the fat reserves of the animal are maintained. Weston (I966) found, when infusing volatile fatty acids for $22 \mathrm{~h}$ each day for 9-14 $\mathrm{d}$, that the 'decrease in metabolizable energy intake from the roughage was of the same order as the energy supplied by the volatile fatty acids...' and that 'the replacement of the fatty acid anions with chloride resulted in less reduction of food intake'. Our results, when compared with Weston's, suggest that his results were the long-term effects of his infusions and, in particular, that the lesser reduction of food intake when chlorides were infused was the result of the adaptation of the sheep. This adaptation to high concentrations of $\mathrm{NaCl}$ in the diet has been observed by Wilson (1967). 
In our experiments, as the quantity of electrolyte added to the rumen increased, so the water intake also increased, most of the water being consumed in the and hour of the feeding period. Bott, Denton \& Weller (1965) have reported that, after dehydration (in which there was a 10\% reduction in body-weight), their sheep drank precisely the quantity of water necessary to rehydrate themselves. If it is assumed in Expts 3-6 and 7-10 that the drinking of water represented a similar precise correction of the depletion of body fluids, then the quantitative importance of the added electrolyte and the food intake upon body fluid depletion is indicated by the regression coefficients relating water intake to the osmolality of electrolyte solution added to the rumen and to the food intake. The multiple regression equations suggest that the effects of increasing the osmolality of the ruminal liquor by the addition of inorganic electrolytes or the sodium salts of volatile fatty acids were very similar. However, the effects of food intake on water intake, which may reflect the dehydration of body tissues due to salivation, were markedly different in the two equations, possibly reflecting the difference in the quality of the chaff used in the two groups of experiments. Forbes (1968) found differences in the relationship between food intake and water intake when feeding sheep on cubed dried grass and hay.

When water was added to the rumen, the food intake of the sheep was increased (Expt I I). The initial effect of the addition of water to the rumen is to reduce ruminal osmolality. In the present experiments, the addition of water was concluded to lower the osmolality at the beginning of the feeding period so that more good-quality lucerne could be ingested before the ruminal contents became hyperosmolar and ruminal hyperosmolality began to inhibit food intake. Although the quantity of water drunk was less when water was added to the rumen, the total quantity of water entering the rumen was greater than when water was not added to the rumen. In addition, the increased food intake would have resulted in increased salivary flow (Wilson, 1962) and thus the total addition of fluid to the rumen was considerably increased.

If food intake was limited by the degree of distension of the rumen then, when water was added to the rumen, the ruminal volume would have increased and the food intake might have been expected to decrease. There was, however, an increase in food intake, an observation supporting the conclusions of Kay (1963) that 'simple stretch of the rumen by the volume of its contents is unlikely to be the only important stimulus to satiation...'. Campling \& Balch (r96r) found that the food intake of cattle was increased by the removal of the ingesta from the rumen, and that the food intake of other cattle was decreased when the same ingesta was placed in their rumens, at the beginning of feeding. The results of the present experiments suggest that Campling \& Balch's results may have been due, at least in part, to modification and exaggeration of the osmolar changes in the rumen, rather than to changes of ruminal bulk.

The authors thank Professor O. E. Budtz-Olsen and Dr D. J. Minson for their encouragement with this work and Professor D. F. Dowling for the use of the facilities within his department. The technical assistance of Messrs P. Amos and M. Knott and the financial assistance of the Rural Bank of Australia and the Australian Meat Research Committee are gratefully acknowledged. The pharmaceutical company, Australian Hoechst, is thanked for their gift of the Furosemide. 


\section{REFERENCES}

Anand, B. K. (1961). Physiol. Rev. 41, 677.

Anonymous (1963). Lasix-International Furosemide Symposium p. 7. Frankfurt: Hoechst.

Blaxter, K. L. (1961). Proc. Easter Sch. agric. Sci. Univ. Nott. 7, 183.

Bott, E., Denton, D. A. \& Weller, S. (1965). F. Physiol., Lond. 176, 323.

Brobeck, J. R. (I 960). In Handbook of Physiology. Sect. 1. Neurophysiology Vol. 2, p. I I 97 . Washington: American Physiological Society.

Campling, R. C. \& Balch, C. C. (1961). Br. F. Nutr. 15, 523.

Cort, J.H. (I966). Electrolytes, Fluid Dynamics, and the Nervous System. New York: Academic Press Inc. Elias, E., Gibson, G. J., Greenwood, L. F., Hunt, J. N. \& Tripp, J. H. (1968). F. Physiol., Lond. I94, 317.

Engelhardt, W. v. (1966). Pflüg. Arch. ges. Physiol. 291, 66R.

Forbes, J. M. (1968), Br. F. Nutr. 22, 33.

Gutman, Y. \& Krausz, M. (1969). Physiol. Behav. 4, 3 I I.

Hunt, J. N. \& Pathak, J. D. (I960). F. Physiol., Lond. I54, 254.

Kay, R. N. B. (1963). F. Dairy Res. 30, 26 r.

Kennedy, G. C. (1961). Proc. Nutr. Soc. 20, 58.

Lepkovsky, S., Lyman, R., Fleming, D., Nagumo, M. \& Dimick, M. M. (1957). Am. F. Physiol. r88, 327.

Montgomery, M. J., Schultz, L. H. \& Baumgardt, B. R. (1963). F. Dairy Sci. 46, I380.

Morgan, C. T. (I964). Physiological Psychology 3rd ed. New York: McGraw Hill.

Rook, J. A. F., Balch, C. C., Campling, R. C. \& Fisher, L. J. (1963). Br. F. Nutr. 17, 399.

Ternouth, J. H. (1968). Res. vet. Sci. 9, 345.

Ulyatt, M. J. (1965). N.Z. $Y l$ agric. Res. 8, 397.

Warner, A. C. I. \& Stacy, B. D. (1965). Q. भl exp. Physiol. 50, r69.

Weston, R. H. (1966). Aust. F. agric. Res. 17, 939.

Wilson, A. D. (1962). Proc. Aust. Soc. Anim. Prod. 4, 53.

Wilson, A. D. (1966). Aust. F. agric. Res. 17, 503.

Wilson, A. D. (1967). Aust. F. agric. Anim. Husb. 7, 321. 